\title{
Acute Tubular Necrosis and Interstitial Nephritis during Pemetrexed Therapy
}

\author{
Judith Michels ${ }^{\mathrm{a}} \quad$ Jean Philippe Spano \\ Isabelle Brocheriou ${ }^{b}$ Gilbert Deray ${ }^{c}$ David Khayat ${ }^{a}$ \\ Hassane Izzedine ${ }^{c}$
}

Departments of a Medical Oncology, bPathology, and 'Nephrology, Pitié-Salpêtrière Hospital, Paris, France

\section{Key Words}

Acute renal failure - Acute tubular necrosis - Interstitial nephritis - Pemetrexed

\begin{abstract}
We report a patient with unknown primary undifferentiated carcinoma who developed acute renal failure associated with interstitial fibrosis following pemetrexed therapy. Despite drug withdrawal, renal function remained altered and the patient experienced chronic renal insufficiency. Pemetrexed disodium (Alimta ${ }^{\mathrm{TM}}$ ) is a multitargeted antifolate agent approved by the Food and Drug Administration (FDA) for patients diagnosed with mesothelioma and non-small cell lung cancer. This drug is almost exclusively cleared by renal excretion [1]. The most common side effects are hematologic dose-limiting toxicities and nonhematologic toxicities including fatigue, diarrhea, nausea, mucositis and rash. Although few cases of renal failure have been published, no study has reported on the renal pathological findings in this setting. We present a case of acute tubular necrosis associated with interstitial fibrosis after pemetrexed therapy.
\end{abstract}

\section{Case Report}

A 53-year-old African man was diagnosed with unknown primary undifferentiated carcinoma with mediastinal lymph nodes and thrombosis of superior vena cava in 1993. Comorbidities included hepatitis $\mathrm{B}$ and $\mathrm{C}$ virus infections. The patient was initially treated by 8 cycles of $\mathrm{CHOP}$ (cyclophosphamide, Adriamycin, vincristine, and prednisone). He relapsed in 1996 with spinal bone metastases treated by laminectomy, radiotherapy and PFL-VP16 (CDDP, 5FU, leucovorin, etoposide). In 1999 he relapsed again with mediastinal lymph nodes treated by 3 cycles of Navelbine and cisplatin followed by 3 cycles of carboplatin and Navelbine with $>70 \%$ treatment response. Biopsy at that time revealed large-cell carcinoma of bronchial or thymic origin. In 2002 newly discovered bone, pulmonary and mediastinal metastases were treated successively with Taxotere/gemcitabine (6 cycles), Navelbine/Xeloda (6 cycles), Iressa (6 months) and Tarceva (8 months). In 2005, pemetrexed was 


\begin{tabular}{|c|c|c|c|}
\hline $\begin{array}{l}\text { Case Reports in } \\
\text { Ena.tily }\end{array}$ & $\begin{array}{l}\text { Case Rep Oncol 2009;2:53-56 } \\
\text { Dol: } 10.1159 / 000208377\end{array}$ & Published online: March 14, 2009 & $\begin{array}{l}\text { (c) } 2009 \text { S. Karger AG, Basel } \\
\text { ISSN } 1662-6575 \\
\text { www.karger.com/cro }\end{array}$ \\
\hline
\end{tabular}

maintained for only 4 cycles, then was suspended due to hematoxicity despite clinical efficiency. His performance status remained acceptable estimated at 1. No maintenance treatment was used until April 2007, when new bone metastases were discovered. The patient was hence treated with pemetrexed, as it once showed its efficacy in 2005. Baseline serum creatinine was $100 \mu \mathrm{mol} / \mathrm{l}$. After the sixth cycle, laboratory examination revealed serum creatinine $400 \mu \mathrm{mol} / \mathrm{l}$, metabolic acidosis (plasma bicarbonate $21 \mathrm{mmol} / \mathrm{l}$ ), sodium $145 \mathrm{mmol} / \mathrm{l}$, potassium $4,5 \mathrm{mmol} / \mathrm{l}$, urea $21 \mathrm{mmol} / \mathrm{l}$. The rate of creatinine clearance was $10 \mathrm{ml} / \mathrm{min}$. A $24-\mathrm{h}$ urine collection on the $2 \mathrm{nd}$ hospital day revealed a $0.55 \mathrm{~g}$ proteinuria without hematuria or leukocyturia.

A kidney biopsy was performed showing acute tubular necrosis (ATN) associated with chronic interstitial fibrosis (fig. 1). The patient underwent intravenous hydration, urine alkalinisation and folinic acid supplementation. The renal function partially recovered within 1 month (serum creatinine $400 \mu \mathrm{mol} / \mathrm{l})$.

His current renal function remained stable after 6 months follow-up of the acute renal failure (ARF) episode with a stable serum creatinine level of $380 \mu \mathrm{mol} / \mathrm{l}$. He is treated with oral VP 16.

\section{Discussion}

Our patient experienced severe acute kidney injury related to ATN and interstitial fibrosis following sequential treatment with pemetrexed for a metastatic undifferentiated carcinoma. Although our patient had previously received cisplatin, ARF appeared only after pemetrexed treatment.

Only few cases of ARF due to pemetrexed have been reported. In a patient treated for metastatic non-small cell lung cancer, ARF was associated with nephrogenic diabetes insipidus and distal renal tubular acidosis following 3 doses of pemetrexed $\left(500 \mathrm{mg} / \mathrm{m}^{2}\right)$. At discharge 1 month after admission, the patient still demonstrated polyuria, hypokalemia, and metabolic acidosis despite recovery to a creatinine level of $1.7 \mathrm{mg} / \mathrm{dl}$ [2].

In a second patient with unresectable pleural mesothelioma, pemetrexed $\left(500 \mathrm{mg} / \mathrm{m}^{2}\right)$ and cisplatin $\left(75 \mathrm{mg} / \mathrm{m}^{2}\right)$ for 3 cycles, then pemetrexed as a single agent induced ARF appearing at the sixth cycle of pemetrexed [3]. Unfortunately, kidney biopsy was not performed. In both cases, ARF was associated with myelosuppression.

Eighteen cases of renal failure during clinical trials of pemetrexed [2] have also been reported. In the phase I pemetrexed maintenance therapy (PMT) study evaluating toxicity as primary end point, $8 \%$ of patients with malignant pleural mesothelioma treated with high doses $\left(700 \mathrm{mg} / \mathrm{m}^{2}\right)$ of pemetrexed experienced reversible grade 1 or 2 renal failure: creatinine clearance decreased from $88 \pm 21 \mathrm{ml} / \mathrm{min}$ at the end of the induction therapy to $77 \pm 26 \mathrm{ml} / \mathrm{min}$ at the end of maintenance therapy $(\mathrm{p}<0.05)$. No grade 4 toxicity was observed [4].

In phase III trials, all grades of renal failure and grade 4 requiring dialysis were reported in 2.4 and $0.6 \%$ of patients, respectively [5]. In all studies, baseline creatinine clearance (estimated using the Cockcroft-Gault formula) less than $60 \mathrm{ml} / \mathrm{min}$ was an exclusion criterion. Indeed, pemetrexed-induced renal toxicity may potentiate an enhanced myelosuppressive response to pemetrexed. In an initial phase I study [6] the development of severe toxicity appeared to correlate most strongly with baseline renal function. Patients with an estimated creatinine clearance value less than $80 \mathrm{ml} / \mathrm{min}$ were more likely to develop severe myelosuppression (grade IV neutropenia) than those with a creatinine clearance more than $80 \mathrm{ml} / \mathrm{min}$. This suggests that initial dosing should be based on the area under the curve as currently utilized for carboplatin rather than on body surface area and renal function. This idea was confirmed by an analysis of 10 phase 


\begin{tabular}{|c|c|c|c|}
\hline $\begin{array}{l}\text { Cose Reports in } \\
\text { Bincisy }\end{array}$ & $\begin{array}{l}\text { Case Rep Oncol 2009;2:53-56 } \\
\text { Dol: } 10.1159 / 000208377\end{array}$ & Published online: March 14, 2009 & \begin{tabular}{|l} 
@ 2009 S. Karger AG, Basel \\
ISSN 1662-6575 \\
www.karger.com/cro
\end{tabular} \\
\hline
\end{tabular}

II clinical trials [7]. In a phase I dose escalation trial including patients with various degrees of renal dysfunction [8], pemetrexed seems to be well tolerated at doses of 500 $\mathrm{mg} / \mathrm{m}^{2}$ with vitamin supplementation in the case of creatinine clearance $\geq 40 \mathrm{ml} / \mathrm{min}$. The FDA even recommends a creatinine clearance of greater than $45 \mathrm{ml} / \mathrm{min}$ as the threshold for administering the drug [9].

Antifolate nephrotoxicity is correlated with renal reabsorption. An experimental study demonstrated that in kidney proximal tubule, the folic acid is reabsorbed via renal folate receptors and brush-border membrane vesicles. The reabsorption of folic acid is increased in acid $\mathrm{pH}$. The observed binding is 3 -fold higher at $\mathrm{pH} 6.0$ than at 7.0 [10]. The hypothesis is that the antifolate, like the folic acid, would be less reabsorbed by urine alkalinisation and increasing urine flow rate by hydration. On the other hand, thymidine is described as an antidote for pemetrexed-related toxicity in a clinical report, though in that report the concomitant use of hemodialysis complicates the interpretation of this favorable outcome [3]. In summary, pemetrexed therapy may induce ATN associated with interstitial fibrosis leading to chronic renal failure.

Fig. 1. Acute tubular injury is characterized by swelling and vacuolization of proximal tubular cells. Cells appear large and contain discrete vacuoles of varying size. Masson's trichrome. Original magnification $\times 200$.

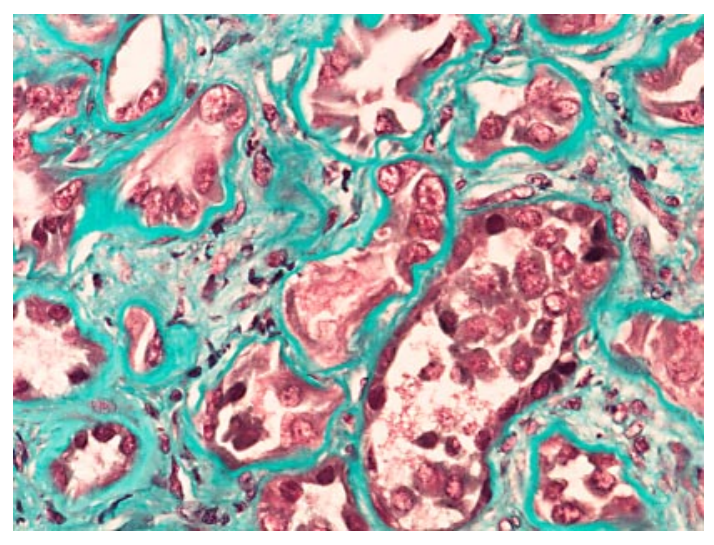




\section{References}

1 Brandes JC, Grossman SA, Ahmad H: Alteration of pemetrexed excretion in the presence of acute renal failure and effusions. Cancer Invest 2006;24:283-287.

2 Vootukuru V, Liew YP, Nally JV: Pemetrexed-induced acute renal failure, nephrogenic diabetes insipidus, and renal tubular acidosis in a patient with nonsmall cell lung cancer. Med Oncol 2006;23:419-422.

3 Castro M: Thymidine rescue: an antidote for pemetrexed-related toxicity in the setting of acute renal failure. J Clin Oncol 2003;21:4066-4069.

4 van den Bogaert DP, Pouw EM, van Wijhe G, Vernhout RM, Surmont VF, Hoogsteden HC, van Klaveren RJ: Pemetrexed maintenance therapy in patients with malignant pleural mesothelioma. J Thorac Oncol 2006;1:25-30.

5 Hazarika M, White RM, Johnson JR, Pazdur R: FDA drug approval summaries: pemetrexed (Alimta). Oncologist 2004;9:482-488.

-6 Rinaldi DA, Kuhn JG, Burris HA, Dorr FA, Rodriguez G, Eckhardt SG, Jones S, Woodworth JR, Baker S, Langley C, Mascorro D, Abrahams T, Von Hoff DD: A phase I evaluation of multitargeted antifolate (MTA, LY231514), administered every 21 days, utilizing the modified continual reassessment method for dose escalation. Cancer Chemother Pharmacol 1999;44:372-380.

7 Latz JE, Chaudhary A, Ghosh A, Johnson RD: Population pharmacokinetic analysis of ten phase II clinical trials of pemetrexed in cancer patients. Cancer Chemother Pharmacol 2006;57:401-411.

-8 Mita AC, Sweeney CJ, Baker SD, Goetz A, Hammond LA, Patnaik A, Tolcher AW, Villalona-Calero M, Sandler A, Chaudhuri T, Molpus K, Latz JE, Simms L, Chaudhary AK, Johnson RD, Rowinsky EK, Takimoto CH: Phase I and pharmacokinetic study of pemetrexed administered every 3 weeks to advanced cancer patients with normal and impaired renal function. J Clin Oncol 2006;24:552-562.

9 U.S. Food and Drug Administration: Center for Drug Evaluation and Research: Alimta, 2004. http://www.fda.gov/cder/foi/label/2004/021677lbl.pdf.

10 Damaraju VL, Hamilton KF, Seth-Smith ML, et al: Characterization of binding of folates and antifolates to brush-border membrane vesicles isolated from human kidney. Mol Pharmacol 2005;67:453-459. 